\title{
Assessment of Immunity Induced in Mice by Glycoproteins Derived from Different Strains and Species of Leishmania
}

\author{
Tânia Mara Pinto Dabés Guimarães, Vicente de Paulo Coelho Peixoto de \\ Toledo*, Carlos Alberto da Costa, Roberto Teodoro da Costa**, Odair \\ Genaro**, Paul Williams**, Wilson Mayrink**
}

\begin{abstract}
Departamento de Análises Clínicas e Toxicológicas, Faculdade de Farmácia, Universidade Federal de Minas Gerais, Caixa Postal 689, 30180-112 Belo Horizonte, MG, Brasil *Departamento de Pesquisas, Biobrás SA, Belo Horizonte, MG, Brasil **Departamento de Parasitologia, Instituto de Ciências Biológicas, Universidade Federal de Minas Gerais, Belo Horizonte, MG, Brasil
\end{abstract}

A comparative study was undertaken on the immunogenic properties of $63 \mathrm{kDa}$ glycoproteins obtained from five different strains/species of Leishmania and assessed in C57BL/10 mice. The humoral immune response was assessed by ELISA against the five different antigens of the immunized animals. The cellular immune response was derived from Leishmania. The response was found to be species-specific in all of determined by means of the cytokine profiles secreted by the spleen cells of immunized animals. The presence of $\gamma-I F N$ and $I L-2$, and the absence of $I L-4$ in the supernatants of cells stimulated by $\mathrm{L}$. amazonensis antigen established that the cellular response is of Th type. The five glycoproteins tested were equally effective in protecting C57BL/10 mice against challenge by L. amazonensis. About $50 \%$ of the immunized animals were protected for six months.

Key words: Leishmania - glycoproteins - monoclonal antibodies

Human leishmaniases are diseases caused by several species belonging to the protozoan genus Leishmania. The clinical spectrum induced by different species of the genus ranges from a single cutaneous lesion that may undergo spontaneous cure to mucocutaneous lesions that can cause grossly disfiguring lesions or diffuse cutaneous lesions that are virtually impossible to treat, and various visceral forms that can be lethal.

American cutaneous leishmaniasis (ACL) is endemic in Central and South America (Garrido 1983). Within these areas, disease prevalence is often high and (WHO 1980) increasing. The available chemotherapeutic agents are toxic and are sometimes ineffective even after long treatment periods (Marsden 1985). Transmission control by using insecticides against the insect hosts (Diptera: Phlebotomidae) of the parasite is virtually impossible. Most of the sand fly species associated with ACL have sylvatic habits.

In recent years, there has been increasing interest in the potential of a vaccine as a mean of controlling and containing ACL. Modabber (1989) has pointed out that vaccination is the simplest and most convenient mean of protecting man against infection by Leishmania. Because of the

Financial support was provided by FINEP, FAPEMIG, CNPQ, PRPQ-UFMG.

Received 3 January 1995

Accepted 18 September 1995 forest-dwelling habits of both the insect and the non-human mammalian host of Leishmania species, vaccination is probably the cheapest longterm mean of control.

Attempts to obtain effective vaccines, and to define their immunogenic elements, have been carried out in several parts of the world. In Brazil, the first attempt to protect a human population against ACL was carried out in the State of São Paulo (Pessoa \& Pestana 1940). Although the results obtained were promising, the potential of vaccination was not further explored until Mayrink et al. (1979) prepared a vaccine composed of killed promastigotes of five strains of Leishmania, each one having been isolated in different endemic areas of ACL in Brazil.

Since the results of the first field trial (Mayrink et al. 1979) were published, modifications have been made in the composition of the vaccine and method of administration. Studies have also been undertaken on storage and stability, and the duration of protection in immunized individuals (Mayrink et al. 1979, 1985, Antunes et al. 1986, Nascimento et al. 1990, Costa et al. 1992). Using the Montenegro antigen developed by Melo et al. (1977), the results of these field trials have shown that about $50 \%$ of vaccinated individuals are protected against ACL. None of the vaccinated patients developed adverse side effects.

Earlier studies (Costa et al. 1990, Nascimento et al. 1990, Tavares et al. 1990, Guimarães et al. 1992) have shown that the $63 \mathrm{kDa}$ glycoprotein 
(GP63) extracted from the complex vaccine of Mayrink et al. (1979) is the most important component inducing immunoprotection in mice. However, Steinkrauss and Langer (1992) found that the GP63 of different species of Leishmania have different genetical code sequences. Against this background, it became necessary to examine and compare the immunostimulator effect of GP63 derived from each of the five strains incorporated in the vaccine.

This report deals with humoral and cellular immune responses observed in C57BL/10 mice immunized with GP63 isolated from each of the component strains of the vaccine. Levels of protection were assessed by challenging immunized mice with $L$. amazonensis and comparing cross reactivity of each strain with anti-GP63 monoclonal antibodies.

\section{MATERIALS AND METHODS}

Parasites - The strains and species used in the present study were the five incorporated into the vaccine of Mayrink et al. (1979): L. (L.) amazonensis (IFLA/BR/67/PH8); L. (L.) mexicana (MHOM/BR/60/BH06); L. (Viannia) guyanensis (MHOM/BR/70/M1176); L. sp. (MHOM/BR/71/ BH49 - major-like); L. sp. (MHOM/BR/73/BH121 - major-like). Promastigotes were grown in LIT culture medium at $23^{\circ} \mathrm{C}$ with transfers every 14 days.

L. amazonensis was used for the challenge infection. Promastigote cultures in NNN/LIT medium were initiated from biopsies taken from the border of a leishmanial lesion on the snout of experimentally infected golden hamsters. The challenge infection consisted of $1 \times 10^{5}$ promastigotes harvested on the 14th day of cultivation.

Mice - BALB/c and C57BL/10 mice were reared in the colonies maintained at the Institute of Biological Sciences, Federal University of Minas Gerais. Females between eight and 12 weeks-ofage were used.

Preparation of antigens - Promastigotes of each of the five species/strains of Leishmania were grown, separately, in LIT medium at $23^{\circ} \mathrm{C}$ for seven days. After centrifuging $1500 \mathrm{~g}$ for $10 \mathrm{~min}$, promastigotes were washed and resuspended three times in physiological saline. The final sediment was disrupted ultrasonically at 40 watts for $1 \mathrm{~min}$, the process being repeated three times. The protein concentration was determined by the method of Lowry et al. (1951). Proteolytic inhibitors (2mM $\mathrm{N}$-tosyl-L-phenylalanine chloromethyl ketone, $2 \mathrm{mM}$ phenylmethylenesulfonyl fluoride, $2 \mathrm{mM} \mathrm{N}$ p-tosyl-L-lysine chloromethyl ketone), and merthiolate, at a concentration of $0,1 \mathrm{mg} / \mathrm{ml}$ were added to each suspension before storage at $-70^{\circ} \mathrm{C}$.
Production of monoclonal antibodies - Monoclonal antibodies (MAbs) were obtained by the method described by Galfré and Milstein (1981). Two $100 \mu \mathrm{g}$ doses of antigen extracts of each of the five species/strains of Leishmania, combined with 250ug of Corynebacterium parvum, were inoculated subcutaneously, with a seven day interval between doses, into the base of the tail of $\mathrm{BALB} / \mathrm{c}$ mice. A booster of $10 \mu \mathrm{g}$ of antigen, without adjuvant, was given intravenously 35 days later. Fusions were carried out four days later, using spleen cells of immunized mice and SP2/0 myeloma cells. The fusion agent was polythylenoglycol (MW 1440, Sigma, USA).

Positive hybridomas were cloned by limiting dilution (Handman \& Hocking 1982). To obtain large amounts of antibodies, cells were inoculated intraperitoneally into BALB/c mice and ascitic fluid was colleted two to three weeks later. Antibody production was assessed by ELISA on the supernatant of the culture and/or the ascitic fluid, using the method of Engval (1980) and the indirect immunofluorescence technique of Camargo (1966). For both reactions, the conjugates used were rabbit antibodies anti-mouse IgG and antimouse IgM, associated, with peroxidase (SigmaUSA) or fluorochrome (Cappel Laboratories).

The isotypic class of the Mabs was determined in the supernatants of cultures of each clone by double immunodiffusion in agarose, using rabbit antibodies anti-IgM of mice and anti-mouse subclasses of $\operatorname{IgG}$ (IgG1, IgG2a, IgG2b and IgG3 Sigma-USA).

Characterization of monoclonal antibodies Approximately $2 \times 10^{7}$ promastigotes of each strain/ species of Leishmania were labelled with $250 \mu \mathrm{ci}$ of $\mathrm{Na}^{125} \mathrm{I}$, using iodogen (Sigma-USA), as described by Lepay et al. (1983). The labelled proteins were dissolved with Triton X-100. Culture supernatants $(50 \mu \mathrm{l})$ containing monoclonal antibodies were added to the marked antigen and kept at $4{ }^{\circ} \mathrm{C}$ for $24 \mathrm{hr}$. Thereafter, $50 \mu \mathrm{l}$ of $50 \%$ SepharosePotein A was added and the mixture was incubated for $60 \mathrm{~min}$ at room temperature. The suspension was washed three times in PBS and resuspended in $30 \mu \mathrm{l}$ of sample buffer $(0,125 \mathrm{M}$ Tris hydrochloride at $\mathrm{pH} 6.8,4 \%$ sodium dodecyl sulphate, $10 \%$ 2-mercaptoethanol, $20 \%$ glycerol). The samples were applied to $10 \%$ polyacrylamide gel which, after electrophoresis, was stained with Coomassie Blue, dried and autoradiographed (Laemmli 1970). The molecular weight of immunoprecipitated proteins was estimated by comparison with molecular weight standards (Sigma-USA).

Purification of GP63 glycoproteins - The antigen extract of each strain/species of Leishmania was purified by an affinity column prepared with CNBr-activated Sepharose CL-4B (Pharmacia- 
USA) coupled to the homologous monoclonal antiGP63. An eluate was made with $200 \mathrm{mM}$ of buffered glycine- $\mathrm{HCl}(\mathrm{pH} 2.8)$. The resultant material was neutralized, lyophilized and then dialyzed against PBS (pH 7.2). The purity of the isolated antigen was assessed by electrophoresis in polyacrylamide gel, stained by the silver method of Wray et al. (1981) and by means of proteolytic activity, using the BApNA substrate method, as described by Erlanger et al. (1961).

Immunization of mice - Isogenic C57BL/10 mice were vaccinated by the method of Costa (1986). Each animal received two subcutaneous inoculations, separated by an interval of seven

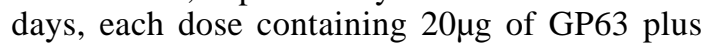
$250 \mu \mathrm{g}$ of $C$. parvum. Twenty-eight days after the second dose, the animals received a further $2 \mu \mathrm{g}$ of GP63, without adjuvant. Seven days after the booster, the animals were challenged with $1 \times 105$ promastigotes of L. amazonensis, inoculated subcutaneously into the base of the tail. The animals were examined at two-week intervals for a total of 180 days after challenge to observe the appearance of lesions and their subsequent development.

Controls - The first control group consisted of C57BL/10 mice immunized with the basic vaccine (prepared from all five strains/species of Leishmania). The second included mice that received only $C$. parvum.

Humoral immune response - This was assessed by examining sera obtained 42 days after the first dose of GP63. ELISA was carried out using $2 \mu \mathrm{g}$ of protein/well of the antigens derived from the five strains/species of Leishmania and rabbit IgG, anti-IgG and anti-IgM associated with peroxidase (Sigma-USA).

Assay for cytokines - Levels of $\gamma$-IFN and IL-4 were determined by immunoenzimatic method in the supernatants of 72-hr cultures of spleen cells $\left(5 \times 10^{6}\right.$ cells $\left./ \mathrm{ml}\right)$ stimulated, by an antigenic extract of $L$. amazonensis. For $\gamma$-IFN, we used the method described by Scott et al. (1987). For IL-4 quantification, monoclonal antibody anti-IL4 adsorbed on a microplate $(2 \mu \mathrm{g} / \mathrm{ml}$ - PharmingenUSA) was used, with $100 \mu$ of each sample. Samples of IL-4 remained in the plates for $4 \mathrm{hr}$ at $25^{\circ} \mathrm{C}$. The material was washed with saline containing 5\% normal calf serum and then incubated for $45 \mathrm{~min}$ with $100 \mu \mathrm{l}$ of anti-IL-4 monoclonal antibody biotinylated at a concentration of $1 \mu \mathrm{g} /$ $\mathrm{ml}$ (Pharmingen-USA). Finally, the conjugate avidin-peroxidase (Pharmingen-USA) was added and the preparation was held at $25^{\circ} \mathrm{C}$ for $30 \mathrm{~min}$. The reaction was revealed by the addition of a buffered substrate containing $150 \mathrm{mg} / 500 \mathrm{ml}$ of ABTS [2,2' Azino-Bis 3-ethylbenzthiazoline-6-sulphonic acid] (Sigma) and hydrogen peroxide, for 10-30 min at $25^{\circ} \mathrm{C}$. Absorbance was measured at $405 \mathrm{~nm}$.

For IL-2, culture supernatants were examined after $24 \mathrm{hr}$. Assessments were made using a commercially available kit (Intertest:Mouse Interleukin -2Elisa kit, Genzyme).

Statistical analysis - Statistical significance was determined by Student $t$ test, analyzing at least two determinations.

\section{RESULTS}

Monoclonal antibodies - In fusions with extracts from the different strains/species of Leishmania, 196 hybrids were obtained, and these provided 85 clones secreting antibodies. The clones showing the greater reactivity by ELISA were characterized by immunoprecipitation (Fig. 1). 95\% of monoclonal antibodies from 85 clones recognized a single antigen with a molecular weight of approximately $63 \mathrm{kDa}$ and $45 \%$ of this were specific to homologous strain and for each strain, a single monoclonal antibody was selected. The antibodies, when tested in RIFI against antigens of the different strains of Leishmania, only reacted with the homologous strain (Table I). When we made the crossed immunoprecipitation with the differents monoclonal antibodies against the antigen extracte of each of five Leishmania species/ strains, all of five monoclonal antibodies reacted only with the homologous GP63.

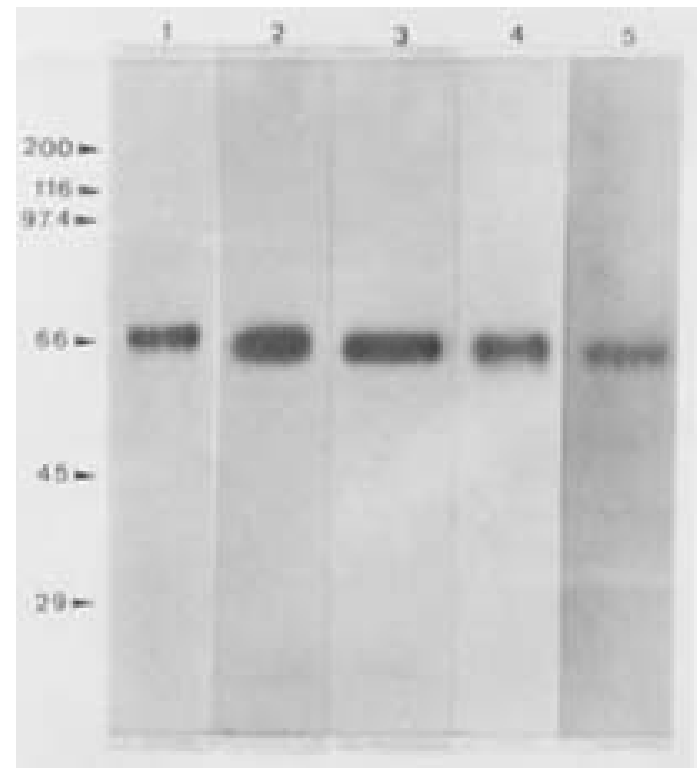

Fig. 1: immunoprecipitation of anti-GP63 monoclonal antibodies derived from five species/strains of Leishmania. 1 - Molecular weight markers in kilodaltons. 2 - L. (L.) mexicana MHOM/ BR/60/BH06 - 33DH10G12. 3 - L. (L.) amazonensis IFLA/BR/ 67/PH8 - 36AE5D10. 4 - L. (L.) sp. MHOM/BR/71/BH49 (major like) - 35AH8B11. 5 - L. (L.) sp. MHOM/BR/73/BH121 (major like) - 28AD2G11. 6 - L. (Viannia) guyanensis MHOM/ $\mathrm{BR} / 70 / \mathrm{M} 1176$ - 68BG12A1. 


\section{TABLE I}

Reaction of monoclonal antibodies against promastigotes of five different strains/species of Leishmania, as revealed by indirect immunofluorescence tests

\begin{tabular}{|c|c|c|c|c|c|}
\hline \multirow[b]{2}{*}{ Strain/Species } & \multicolumn{5}{|c|}{ Monoclonal antibodies } \\
\hline & $33 \mathrm{DH} 10 \mathrm{G}_{12}{ }^{a}$ & $36 \mathrm{AE}_{5} \mathrm{D}_{10}^{b}$ & $35 \mathrm{AH}^{2} \mathrm{~B}_{11}{ }^{c}$ & $28 \mathrm{AD}_{2} \mathrm{G}_{11}^{d}$ & $68 \mathrm{BG}_{12} \mathrm{~A}_{1}{ }^{e}$ \\
\hline $\begin{array}{l}\text { L. mexicana } \\
(\mathrm{MHOM} / \mathrm{BR} / 60 / \mathrm{BH} 06)\end{array}$ & + & - & - & - & - \\
\hline $\begin{array}{l}\text { L. amazonensis } \\
\text { (IFLA/BR/67/pH8) }\end{array}$ & - & + & - & - & - \\
\hline $\begin{array}{l}\text { L. sp. (major like) } \\
(\mathrm{MHOM} / 1 / \mathrm{BR} / 71 / \mathrm{BH} 49)\end{array}$ & - & - & + & - & - \\
\hline $\begin{array}{l}\text { L. sp. (major like) } \\
(\mathrm{MHOM} / 1 / \mathrm{BR} / 73 / \mathrm{BH} 121)\end{array}$ & - & - & - & + & - \\
\hline $\begin{array}{l}\text { L. guyanensis } \\
\text { (MHOM/BR/70/M1176) }\end{array}$ & - & - & - & - & + \\
\hline
\end{tabular}

$a$ : monoclonal antibody to $\mathrm{BH} 06 ; b$ : monoclonal antibody to $\mathrm{pH} 8 ; c$ : monoclonal antibody to $\mathrm{BH} 49$; $d$ : monoclonal antibody to $\mathrm{BH} 121 ; e$ : monoclonal antibody to M1176

Isolation of GP63 from the different strains of Leishmania - The chosen monoclonal antibodies proved to be efficient in isolating different antigens of high purity. Fig. 2 shows the single band for the different purified GP63 of each of the constituent species/strains of the vaccine. The mean return obtained in affinity columns was $60 \mu \mathrm{g}$ of purified antigen for $750 \mathrm{mg}$ of applied antigen extract. When we assayed the proteolytic activity of each purified GP63 after they had been incubated on a BApNA substrate, $\left(\mathrm{N}^{\alpha}\right.$ benzoyl-L-arginine p-nitroanilide chloridrate), with or without a metaloprotease inhibitor (ortho-phenanthroline), we demonstrated that the isolated glycoproteins displayed an intense proteolytic activity that was blocked by the action of ortho-phenantroline.

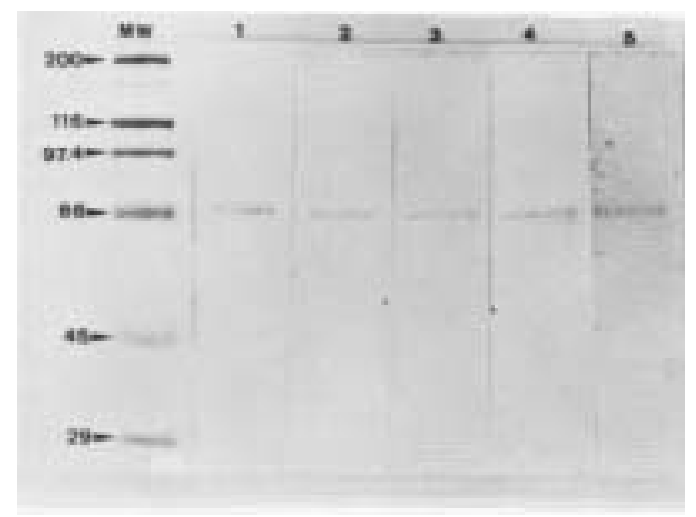

Fig. 2: polyacrilamide gel electrophoresis, stained with silver nitrate, of different GP63s purified by immunoaffinity. 1 - GP63 of Leishmania (L.) mexicana (MHOM/BR/60/BH06). 2 - GP63 of L. (L.) amazonensis (IFLA/BR/67/PH8). 3 - GP63 of $L$. (L.) sp. - major like (MHOM/BR/71/BH49). 4 - GP63 of $L$. (L.) sp major like (MHOM/BR/73/BH121). 5 - GP63 of L. (Viannia) guyanensis (MHOM/BR/70/M1176). MW - Molecular weight markers in kilodaltons.
Humoral immune response - Fig. 3 shows the levels of $\operatorname{IgM}$ and $\mathrm{IgG}$ antibodies on the 42nd day after the first immunizing dose given to C57BL/ 10 mice. In all the groups of vaccinated animals, the levels of IgM antibodies were higher than those of $\mathrm{IgG}$.

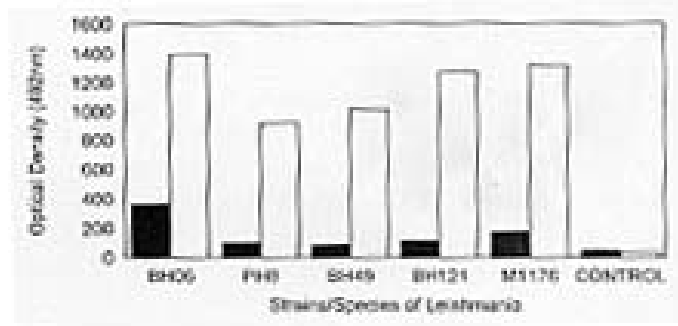

Fig. 3: levels of IgG and IgM antibodies detected in sera obtained from mice that had been immunized 42 days earlier with GP63s of different strains/species of Leishmania. Antibody levels were determined by ELISA using extracts of the promastigotes of each strain/species. The data represents the absorbance of a serum pool (five animals) for each group at a dilution of 1/50. Control $=$ serum pool of normal mice $\mathrm{IgG}, \square \mathrm{IgM}$.

Fig. 4 shows the results of cross reactions, by ELISA, between the sera of mice immunized with the purified GP63s and the different strains of Leishmania. Analysis of these results reveals a specific humoral response to the tested antigens; in each case, the reaction to the homologous strain was statistically significant $(\mathrm{P}<0.05)$.

Cellular immune response - Table II shows that spleen cells of mice immunized with one of the five different GP63s produced $\gamma$-IFN and IL-2, when stimulated in vitro with a total extract of $L$. amazonensis. IL-4 was not detected. 
Development of immunoprotection in mice Fig. 5 summarizes the results obtained when different groups of experimental animals were immunized with different glycoproteins and challenged with L. amazonensis. All controls developed lesions within 60 days of challenge. Only $10-20 \%$ of immunized mice developed lesions. About six months after challenge, all of the control mice had lesions, whereas only $50 \%$ of immunized animals showed signs of infection.

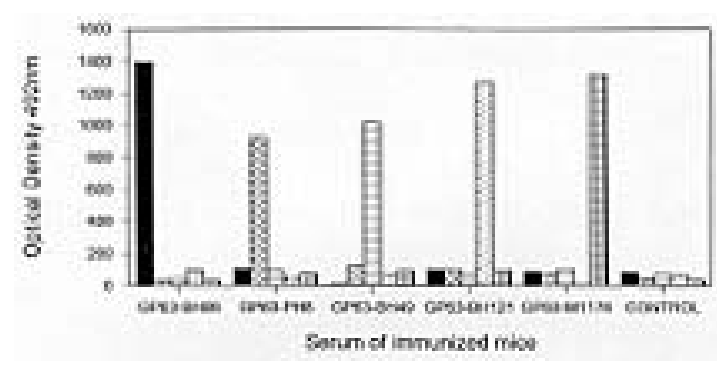

Fig. 4: levels of IgM antibodies in sera of C57BL/10 mice immunized with different GP63s, as determined by ELISA, using antigens of five different strains/species of Leishmania. - BH06 $\square$ pH8 $\square$ BH49 $\square$ BH121 $\square$ M1176. The data represents the absorbance of a serum pool (five animals) for each group at a dilution of $1 / 50$.

\section{TABLE II}

Cytokine production by spleen cells of C57BL/10

mice following immunization with one of five purified GP63 $3_{\mathrm{s}}$ derived from different strains/species of Leishmania

\begin{tabular}{crcc}
\hline \multirow{2}{*}{$\begin{array}{l}\text { Immunization } \\
\text { with } \mathrm{GP}_{63} \text { of }\end{array}$} & \multicolumn{3}{c}{ Citokine (U/ml) } \\
\cline { 2 - 4 } & $\gamma$-IFN & IL-2 & IL-4 \\
\hline BHO6 & 25.2 & 36.3 & 0 \\
PH8 & 17.6 & 54.5 & 0 \\
BH49 & 102.0 & 39.6 & 0 \\
BH121 & 52.0 & 56.1 & 0 \\
M1176 & 17.2 & 45.1 & 0 \\
\hline
\end{tabular}

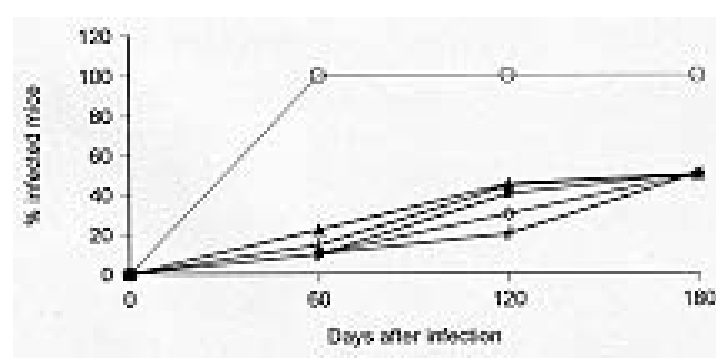

Fig. 5: percentages of C57BL/10 mice immunized with GP63 of different strains/species of Leishmania, developing leishmanial lesions after challenge by inoculation of promastigotes of $L$. amazonensis (IFLA/BR/67/PH8). $\mathrm{n}=10$ mice per group; GP63 - M1176; \# GP63 - BH 121; GP63-pH8; • GP63-BH49; * GP63 - BH06; --- control.

\section{DISCUSSION}

Mayrink et al. (1978) showed that extracts of killed promastigotes of Leishmania, when injected into human subjects, can induce changes in cutaneous reactions to Leishmania antigens. Mayrink et al. (1985) and Antunes et al. (1986) established that the changes in cutaneous responses to Leishmania are correlated with the development of immunoprotection in man. Comparable results were obtained in experiments with mice (Costa 1986, Costa et al. 1992). Other studies (Nascimento et al. 1990) showed that the vaccine of Mayrink et al. (1979) induces a humoral response characterized by low levels of IgG but elevation of IgM. In relation to cellular immunity, it has been shown that cutaneous hypersensitivity is due to lymphocyte proliferation following Leishmania antigen stimulation and the presence of IL2 and $\gamma$-IFN in the supernatants of tissue cultures of vaccinated individuals (Mendonça et al. 1993). Analysis of the phenotype of T lymphocytes has revealed a predominance of $\mathrm{LT} \mathrm{CD}^{+}$in vaccinated individuals but a predominance of $\mathrm{LT} \mathrm{CD} 4^{+}$ in patients with active lesions (Mendonça et al. 1993).

The vaccine against ACL developed by Mayrink et al. (1979) was composed of five strains/ species of Leishmania isolated from different parts of Brazil. The strains/species isolated from human subjects were each associated with different clinical forms of leishmaniasis.

Monoclonal antibodies against each of the five components of the originally described vaccine were developed in the present study. The monoclonal antibodies selected for study are those that recognize GP63, known to be an immunogenic protein (Tavares et al. 1990, Burns et al. 1991, Russo et al. 1991, Yang et al. 1991), present in the membrane of promastigotes (Etges et al. 1985, 1986, Chaudhuri \& Chang 1988); it is involved in the interaction between promastigotes and macrophages (Chang \& Chang 1986, Russell \& Wilhem 1986), and promotes the development of immunoprotection in mice (Costa et al. 1988, Russell \& Alexander 1988, Tavares et al. 1990, Yang et al. 1991).

The monoclonal antibodies were tested against promastigote antigens of homologous and heterologous strains by means of indirect immunofluorescence reactions. Those showing marked specificity, that reacted only to the homologous strain, were selected for the isolation of the GP63s of each of the five strains. Isolates with a high level of purity were obtained by affinity chromatography and confirmed by polyacrylamide gel electrophoresis using silver nitrate as the stain. Biochemical 
analysis of the purified glycoproteins showed that intense proteolytic activity was due to a metalloprotease, a characteristic of GP63 (Etges et al. 1986, Chaudhuri \& Chang 1988, Chaudhuri et al. 1989).

Immunization of C57BL/10 mice with the different GP63 proteins led to the production of $\operatorname{IgG}$ and IgM antibodies, especially the latter. A similar observation was made by Nascimento et al. (1990) in studies on the sera of individuals immunized with the vaccine of Mayrink et al. (1978, 1979). In the present study, antibodies in the sera of immunized mice, when assessed by immunoenzymatic methods, showed specific responses to the GP63 of the homologous strain. This is an additional evidence of the high level of purification attainable by the methods used to isolate the antigens.

An important feature in characterizing the responses induced by immunization with purified glycoproteins was the detection of $\gamma$-IFN and IL-2 in the supernatants of tissue cultures of spleen cells from immunized mice, after stimulation by extracts of $L$. amazonensis promastigotes. The cellular immune response to promastigote antigens of L.amazonensis was observed in animals immunized with glycoproteins other than those of $L$. amazonensis, thus contrasting with the specific responses in humoral immunity.

Convit et al. (1972), Mitchell (1984) and Mendonça et al. (1986) considered that the mechanisms involved in the cellular immune response are of fundamental importance in establishing protective immunity against ACL. The present results confirm the findings of Nascimento et al. (1990) and Russo et al. (1991) by showing that GP63 is the important protein in the protective process and that the greatest part of the cellular immune response to the parasite is undoubtedly against GP63. Despite the evidence of Steinkrauss and Langer (1992) that GP63 is coded by different sequences in different species of Leishmania, the present results reveal that the cellular immune response (at least in C57BL/10 mice) against the glycoprotein is not predominantly directed towards species-specific epitopes.

This is not surprising as GP63 is highly conserved among the species of Leishmania and Russo et al. (1991), Button et al. (1991) have previously reported cross-reactive $\mathrm{T}$ cell responses to the complete protein, although cross-reacting epitopes had not been previously defined. This variability at the sites of dominant $\mathrm{T}$ cell epitopes may be one mechanism of parasite survival. Although the significant finding that cross-reactive epitopes existed in GP63, it was possible that dominant speciesspecific epitopes also exist (Russo et al. 1993). This situation has been shown in murine models (Jardim et al. 1990, Yang et al. 1991). In addition, human $\mathrm{T}$ cells from individuals with cutaneous, mucosal or cured visceral Leishmaniasis respond in vitro to certain peptides of GP63. Antigenic and immunogenic GP63 peptide sequences have been defined, some appearing to be conserved among Leishmania species and others to be species-specific (Russo et al. 1993). When crossed immunoprecipitation was performed, each monoclonal antibody only recognized the homologous GP63, showing that, in fact, species-specific epitopes are conserved among the different GP63 of Leishmania species.

When animals immunized with different GP63s were challenged with promastigotes of $L$. amazonensis, $50 \%$ of the animals, irrespective of the immunizing agent, failed to develop lesions in 180 days. This level of protection is similar to that observed by Costa et al. (1992) after animals had been immunized with the complex vaccine: that is, with a "cocktail" of five strains.

The studies of Champsi and McMahon-Pratt (1988), Lohman et al. (1990) and Tavares et al. (1990) on purified molecules of extracts of promastigotes have shown the existence of other antigens that induce immunoprotection against cutaneous leishmaniasis in mice. Tavares et al. (1990), using an association of $63 \mathrm{kDa}$ and $97 \mathrm{kDa}$ isolated from the vaccine of Mayrink et al. (1979), recorded a higher degree of protection than that obtained in mice immunized with the complete vaccine, when promastigotes of $L$. amazonensis were used as the challenge.

It can be concluded that purified antigens induce protective immunity against cutaneous leishmaniasis in C57BL/10 mice, that the antigen GP63 is of importance in the development of the immune process, and that there is cross immunity induced by this glycoprotein derived from different species/strains of New World Leishmania species causing human ACL.

\section{ACKNOWLEDGEMENTS}

To Dr Rosângela Barbosa de Deus for technical assistance with the GP63 proteolytic activity determination and to Dr Phillip Scott for providing compounds used in $\gamma$-IFN analysis.

\section{REFERENCES}

Antunes CMF, Mayrink W, Magalhães PA, Costa CA da, Melo MN, Dias M, Michalick MSM, Williams P, Oliveira-Lima A, Vieira JBF, Schettini APM 1986. Controlled field trial against New World $\mathrm{Cu}-$ taneous Leishmaniasis. Int J Epidemiol 15: 572 580.

Burns Jr JM, Scott JM, Carvalho EM, Russo DM, March CJ, Van Ness KP, Reed SG 1991. Characterization 
of a membrane antigen of Leishmania amazonensis that stimulates human immune responses. $J$ Immunol 146: 742-748.

Button LL, Reiner NE, McMaster WR 1991. Modification of Leishmania GP63 genes by the polymerase chain reaction for expression of nonfusion protein at high levels of Escherichia coli: application to mapping protective $\mathrm{T}$ cell determinants. Mol Biochem Parasitol 44: 213-216.

Camargo ME 1966. Fluorescent antibody for the serodiagnosis of American Trypanosomiasis. Technical modification employing preserved culture forms of Trypanosoma cruzi in a slide test. Rev Inst Med Trop São Paulo 8: 227-234.

Champsi J, McMahon-Pratt 1988. Membrane Glycoprotein M-2 protects against Leishmania amazonensis infection. Infect Immun 52: 3272-3279.

Chang CS, Chang KP 1986. Monoclonal antibody affinity purification of a Leishmania membrane glycoprotein and its inhibition of Leishmania-macrophage binding. Proc Natl Acad Sci USA 83: 100-104.

Chaudhuri G, Chang KP 1988. Acid protease activity of a major surface membrane glycoprotein (GP63) from Leishmania mexicana promastigotes. Mol Biochem Parasitol 27: 43-52.

Chaudhuri G, Chaudhuri M, Pan A, Chang KP 1989. Surface acid proteinase (GP63) of Leishmania mexicana. J Biol Chem 264: 7483-7489.

Convit J, Pinardi ME, Rondon AJ 1972. Diffuse cutaneous leishmaniasis: A disease due to an immunological defect of the host. Trans $R$ Soc Trop Med Hyg 66: 603-610.

Costa CA da 1986. Infecção experimental do camundongo isogênico C57BL/10 com Leishmania mexicana amazonensis, estudos da atividade imunogênica de uma vacina com promastigotas mortas. PhD Thesis. Universidade Federal de Minas Gerais, Belo Horizonte, 168 pp.

Costa CA da, Afonso LCC, Tavares CAP, Nascimento E, Dabés TMP, Mayrink W 1990. Protective antigens isolated from a vaccine against cutaneous leishmaniasis. p. 28-29 Meeting on vaccines against leishmaniasis. UFMG-ICB, Belo Horizonte..

Costa CA da, Afonso LCC, Toledo VPCP, Nascimento E, Tavares CAP, Mayrink W 1992. Evaluation of an industrialized non living promastigote vaccine against cutaneous leishmaniasis. Parassitologia 34: 45-51.

Costa CA da, Nascimento E, Dabés TMP, Afonso LCC, Taboada DC, Santos Lima M, Tavares CAP, Michalick MSM, Melo MN, Dias M, Costa RT da, Mayrink W 1988. Vacinação de camundongos com antígeno de Leishmania purificado por anticorpos monoclonais. III Reunião Anual da Federação das Sociedades de Biologia Experimental, Caxambu, 385 pp.

Engvall E 1980. Enzyme Immunoassay ELISA and Emit. Methods Enzimol 70: 419-423.

Erlanger BF, Kokowsky N, Cohen W 1961. The preparation and properties of two new chromogenic substrates of trypsin. Arch Biochem Biophys 95: 271278.
Etges R, Bouvier J, Bouvier C 1986. The major surface protein of Leishmania promastigotes is a protease. J Biol Chem 261: 9098-9101.

Etges R, Bouvier J, Hoffman R, Bordier C 1985. Evidence that the major surface protein of three Leishmania species are structurally related. Mol Biochem Parasitol 14: 141-149.

Garrido RB 1983. Leishmanias by leishmaniasis tegumentaria on América Latina. Bol Of Sanit Panam 95: 418-426.

Galfré G, Milstein C 1981. Preparation of monoclonal antibodies: strategies and procedures. Meth Enzymol 73: 3-46.

Guimarães TMPD, Toledo VPCP, França-Silva JC, Hermeto MV, Genaro O, Costa RT, Nascimento E, Tavares CAP, Mayrink W 1992. Vaccination of dogs and mice against cutaneous Leishmaniasis with purified antigens of Leishmania (Leishmania) amazonensis. Mem Inst Oswaldo Cruz 87(Suppl. II): 59.

Handman E, Hocking RE 1982. Stage-specific, strainspecific, and cross-reactive antigens of Leishmania species identified by monoclonal antibodies. Infect Immun 37: 28-33.

Jardim A, Alexander J, Teh SH, Ou D, Olafson RW 1990. Immunoprotective Leishmania major synthetic T cell epitopes. J Exp Med 172: 645-650

Laemmli UK 1970. Cleavage of structural proteins during the assembly of the head of bacteriophage T4. Nature 27: 680-685.

Lepay DA, Nogueira N, Cohn Z 1983. Surface antigens of Leishmania donovani promastigotes. J Exp Med 157: 1562-1572.

Lohman HL, Langer PJ, McMahon-Pratt D 1990. Molecular cloning and characterization of the immunologically protective surface glycoprotein GP46/ M2 of Leishmania amazonensis. Proc Natl Acad Sci USA 87: 8393-8397.

Lowry OH, Rosebrough NJ, Farr AL, Raudall RJ 1951. Protein measurement with the Folin phenol reagent. J Biol Chem 193: 265-275.

Marsden PD 1985. Pentavalent antimonials: Old drugs for new diseases. Rev Soc Bras Med Trop 18: 187198.

Mayrink W, Costa CA da, Magalhães PA, Melo MN, Dias M, Michalick MSM, Williams P 1979. A field trial of a vaccine against American Dermal Leishmaniasis. Trans R Soc Trop Med Hyg 73: 385387.

Mayrink W, Magalhães PA, Dias M, Costa CA da, Melo MN, Oliveira-Lima A 1978. Response to Montenegro antigen after immunization with killed Leishmania promastigotes. Trans $R$ Soc Trop Med Hyg 72: 676-679.

Mayrink W, Williams P, Costa CA da, Magalhães PA, Melo MN, Dias M, Oliveira Lima A, Michalick MSM, Carvalho EF, Barros GC, Sessa PA, Alencar JTA 1985. An experimental vaccine against American dermal leishmaniasis: experience in the state of Espírito Santo, Brasil. Ann Trop Med Parasit 79: 259-269.

Melo MN, Mayrink W, Costa CA da, Magalhães PA, 
Dias M, Williams P, Araújo FG, Coelho MV, Batista SM 1977. Padronização do antígeno de Montenegro. Rev Inst Med Trop São Paulo 19: 161-164.

Mendonça SC, Coutinho SG, Amendoeira RR, Marzochi MCA, Pirmez C 1986. Human American cutaneous leishmaniasis (L. b. braziliensis) in Brazil: lymphoproliferative responses and influence of therapy. Clin Exp Immunol 64: 269-276.

Mendonça SCF, de Luca PM, Mayrink W, da Cruz AM, Conceição-Silva F, Restom T, Costa CA, Genaro O, Oliveira MP, Coutinho SG 1993. Characterization of the cell mediated immune responses induced by a vaccine against American tegumentary leishmaniasis in humans. Mem Inst Oswaldo Cruz 88, (Suppl.): 46.

Mitchell GF 1984. Host-protective immunity and its suppression in a parasitic disease: murine cutaneous leishmaniasis. Immunol Today 5: 221-223.

Modabber F 1989. Experiences with vaccines against cutaneous leishmaniasis of men and mice. Parasitology 98: 549-560.

Nascimento E, Mayrink W, Costa CA da, Michalick MSM, Melo MN, Barros GC, Dias M, Antunes CMF, Lima MS, Taboada DC, Liu TY 1990. Vaccination of humans against cutaneous leishmaniasis: Cellular and humoral immune responses. Infect Immun 58: 2198-2203.

Pessoa SB, Pestana BR 1940. Ensaio sobre a vacinação preventiva na leishmaniose tegumentar americana com leptomonas mortas. Rev Biol Hig 10: 112-118.

Russel DG, Alexander J 1988. Effective immunization against cutaneous leishmaniasis with defined membrane-antigens reconstituted into liposomes. $J$ Immunol 140: 1274-1277.

Russel DG, Wihelm H 1986. The involvement of the major surface glycoprotein (GP63) of Leishmania promastigotes in the attachment to macrophages. $J$
Immunol 136: 2613-2627.

Russo DM, Burns Jr JM, Carvalho EM, Armitage RJ, Grabstein KH, Button LL, McMaster WR, Reed SG 1991. Human T cell responses to GP63, a surface antigen of Leishmania. J Immunol 147: 3575-3580.

Russo DM, Jardim A, Carvalho EM, Sleath PR, Armitage RJ, Olafson RW, Reed SG 1993. Mapping human $\mathrm{T}$ cell epitopes in Leishmania GP63. Identification of cross-reactive and species-specific epitopes. J Immunol 150: 932-939.

Scott P, Pearce E, Natovitz P, Sher A 1987. Vaccination against cutaneous leishmaniasis in a murine model: I. Induction of protective immunity with a soluble extract of promastigotes. J Immunol 139: 221-227.

Steinkrauss H, Langer PJ 1992. The protein sequence predicted from a Leishmania guyanensis gp63 major surface glycoprotein gene is divergent as compared with other Leishmania species. Molec Biochem Parasit 52: 141-144.

Tavares CAP, Costa CA da, Afonso LCC, Nascimento E, Guimarães TMPD, Melo MN, Michalick MSM, Mares-Guia ML, Mayrink W 1990. Identification, characterization and isolation of antigens from a vaccine against New World Cutaneous Leishmaniasis. p. 74. Meeting on vaccines against leishmaniasis, UFMG-ICB, Belo Horizonte.

Yang DM, Rogers MV, Liew FY 1991. Identification and characterization of host-protective T-cell epitopes of a major surface glycoprotein (GP63) from Leishmania major. Immunology 72: 3-9.

WHO/UNDP/World Bank 1980. Special programme for research and training in tropical disease, p. 173191. Fourth Annual Report.

Wray W, Boulikas T, Wray VP, Hancock R 1961. Silver Staining of Proteins in Polyacrylamide Gels. Analyt Biochem 118: 197-203. 